\title{
Esmolol as an Adjunct to General Balanced Anaesthesia in Neurosurgery
}

\author{
Dragana Lončar-Stojiljković, , 2, 3 Žana M Maksimović, ${ }^{4,5}$ Marko Djuric ${ }^{6,7}$
}

\section{Abstract}

Background / Aim: In surgery, and especially in the neurosurgical operations, maintenance of cardiovascular stability during and in the phase of the immediate postoperative recovery is of vital importance. The aim of this study was to investigate the effects of continuous esmolol infusion on the values of cardiovascular parameters and quality of the emergence from anaesthesia in neurosurgical patients.

Methods: A total of 40 patients of both sexes scheduled for elective supratentorial surgery were randomly assigned to two groups. Esmolol group received intravenous (iv) infusion of esmolol dissolved in $5 \%$ glucose solution (during the first $5 \mathrm{~min}$ at a rate of $0.3 \mathrm{mg} / \mathrm{kg} / \mathrm{min}$ and thereafter at a rate of $0.1 \mathrm{mg} / \mathrm{kg} / \mathrm{min}$ ), while the ones from the control group received a $5 \%$ glucose solution without esmolol at the same volume and rate. Cardiovascular parameters were registered at critical phases of anaesthesia and operation (induction, intubation, placement of Mayfield frame, craniotomy, skull closure, extubation). Recovery after anaesthesia was assessed based on times of eye opening on command, spontaneous eye opening and regaining of full orientation.

Results: Values of systolic blood pressure and heart rate were significantly lower in the esmolol than in the control group of patients. Although the durations of anaesthesia did not differ, patients from the esmolol group required significantly less opioids and isoflurane and recovered after the anaesthesia significantly faster than the patients in the control group.

Conclusion: Ultrashort-acting beta-adrenergic receptor antagonist esmolol, administered as a continuous iv infusion, assures better cardiovascular stability and smoother emergence from the balanced inhalation general anaesthesia than the control glucose infusion in elective neurosurgical patients.

Key words: Beta-adrenergic receptor antagonists; Esmolol; General anaesthesia; Hypertension; Tachycardia.
(1) Department of Anaesthesia and Intensive Therapy, Institute for Cardiovascular Diseases "Dedinje", Belgrade, Serbia.

(2) Department of Anaesthesiology and Reanimatology, Faculty of Medicine, University of Banja Luka, Banja Luka, the Republic of Srpska, Bosnia and Herzegovina.

(3) Clinic for Anaesthesiology and Intensive Therapy, Military Medical Academy, Belgrade, Serbia.

(4) Primary Healthcare Centre Modriča, Modriča, the Republic of Srpska, Bosnia and Herzegovina.

(5) Centre for Biomedical Research, Faculty of Medicine, University of Banja Luka, Banja Luka, the Republic of Srpska, Bosnia and Herzegovina.

(6) Clinic of Anaesthesiology and Reanimatology, Clinical Hospital Centre "Dr Dragiša Mišović - Dedinje", Belgrade, Serbia.

(7) Department of Anaesthesiology and Reanimatology, Faculty of Medicine, University of Belgrade, Belgrade, Serbia.

Correspondence:

DRAGANA

LONČAR-STOJILJKOVIĆ

E: dragana.loncar-stojiljkovic@ med.unibl.org

\section{ARTICLE INFO}

Received: 20 December 202 Revision received: 28 December 2021 Accepted: 29 December 2021

\section{Introduction}

Surgical trauma activates numerous neurohumoral mechanisms, including increased secretion of catecholamines, followed by hypertension and tachycardia. ${ }^{1}$ Modern anaesthetic techniques tend to use a combination of various drugs with the aim to prevent or at least alleviate such reflexes. Usually, this combination includes premedication with benzodiazepines, intubation under the use of short-acting neuromuscular relaxants, induction to anaesthesia with barbiturates, maintenance inhalation and/or intravenous anaesthetics, opioid analgesics, use of competitive neuromuscular blockers and, at the end, of atropine and neostigmine for the decurarisation purposes. ${ }^{2}$ 
Esmolol, as a rapid-acting and titratable beta-adrenergic receptor antagonist, turned out to be an important addition to this concept of general balanced anaesthesia. ${ }^{3}$ Its was used to treat the episodes of hypertension and tachycardia, first in cardiac surgery ${ }^{4,5}$ and thereafter in all other similar indications, ${ }^{6,7}$ including the electroconvulsive therapy. ${ }^{8}$

There are some critical phases of anaesthesia and operation where a proper cardiovascular control is needed. In neurosurgery specifically, these moments include induction, tracheal intubation, placement of the Mayfield frame, craniotomy, skull closure, skin suture and extubation. ${ }^{9}, 10$ Fasttrack emergence from neuro-anaesthesia in order to early detect the possible neurological sequelae is usually accompanied by the increased sympathetic activity, hypertension, tachycardia and increased cerebral perfusion pressure, which all put patients at risk for the development of the postoperative haemorrhage and cerebral haematoma. ${ }^{11}$

For these reasons, the aim of this study was to ascertain the effects of the continuous esmolol infusion on the cardiovascular parameters and other indicators of the quality of anaesthesia in patients scheduled for elective supratentorial surgery.

\section{Methods}

A total of 40 American Society of Anesthesiologists (ASA) I or II category patients aged 18-80 years and scheduled for elective supratentorial surgery were enrolled in this clinical study, after signing an informed consent. The study had previously been approved by the local ethics committee. Patients were randomly assigned to two groups by using the block randomisation.

All of them were subjected to standard premedication and general anaesthesia technique. The only difference was in the fact that the patients from the esmolol group received intravenous (iv) infusion of esmolol dissolved in $5 \%$ glucose solution (during the first $5 \mathrm{~min}$ at a rate of $0.3 \mathrm{mg} / \mathrm{kg} /$ min and thereafter at a rate of $0.1 \mathrm{mg} / \mathrm{kg} / \mathrm{min}$ ), while the ones from the control group received a $5 \%$ glucose solution without esmolol at the same volume and rate.
Esmolol $5 \mathrm{~g}$ was dissolved in a bottle containing $500 \mathrm{~mL}$ of $5 \%$ glucose solution, yielding the final concentration of $10 \mathrm{mg} / \mathrm{mL}$. The speed of the iv infusion in both groups was $0.03 \mathrm{~mL} / \mathrm{kg} / \mathrm{min}$ during the first $5 \mathrm{~min}$ and $0.01 \mathrm{~mL} / \mathrm{kg} / \mathrm{min}$ thereafter. The speed of the maintenance iv infusion of esmolol was set at $0.1 \mathrm{mg} / \mathrm{kg} / \mathrm{min}$, since it had been earlier revealed that hypertension rarely occurs at the infusion rates below $0.15 \mathrm{mg} / \mathrm{kg} / \mathrm{min}^{12}$ and because it had been ascertained in a separate dose-finding clinical study that the esmolol infusion rate that did not affect the baseline cardiovascular parameters by more than $10 \%$ was $0.118 \mathrm{mg} / \mathrm{kg} / \mathrm{min}^{13}$

Premedication technique in all the patients consisted of diazepam $10 \mathrm{mg}$ intramuscularly (im) 30-45 min before induction into anaesthesia with thiopentone $3-5 \mathrm{mg} / \mathrm{kg}$ iv and fentanyl $1.5 \mu \mathrm{g} / \mathrm{kg}$. Tracheal intubation was facilitated with suxamethonium 1-2 mg/kg iv. Long-lasting neuromuscular blockade was maintained with pancuronium bromide $0.07 \mathrm{mg} / \mathrm{kg}$ iv. In case of need, incremental iv boluses of pancuronium bromide $0.01 \mathrm{mg} /$ $\mathrm{kg}$ were administered. Nitrous oxide and oxygen (2:1) were used by inhalation for anaesthesia maintenance. At the end of operation, atropine $0.5 \mathrm{mg}$ and neostigmine $1.5 \mathrm{mg}$ were used for the neutralisation of the neuromuscular block.

An increase in systolic blood pressure or heart rate by more than $20 \%$ of the pre-induction values was treated with an iv bolus of fentanyl 1.5 $\mu \mathrm{g} / \mathrm{kg}$ alone, or with droperidol at the ratio 1:50 (in a form of Thalamonal ${ }^{\circledR}$ ). In case that a bolus of fentanyl or Thalamonal ${ }^{\circledR}$ would not be sufficient to treat an episode of hypertension or tachycardia, isoflurane $0.5 \%$ was added into the inhalation mixture. An iv bolus of atropine $0.5 \mathrm{mg}$ was injected to treat episodes of bradycardia, defined as decrease in heart rate by more than $20 \%$ of the pre-induction values.

Quality of anaesthesia was estimated by the attending anaesthesiologist by using the following scale: 1 - bad, 2 - good and 3 - excellent.

Parametric tests - Student t test and ANOVA - and non-parametric test Chi-square were used for statistical analysis. For these purposes the Statistical Package for Social Sciences (SPSS) version 18.0 was utilised. 


\section{Results}

The two studied groups of patients were equal (20 patients each) and not significantly different from each other regarding their demographic characteristics and mean pre-induction values of cardiovascular parameters (Table 1).n a form of Thalamonal).

Table 1: Demographic data and preinduction values of the cardiovascular parameters in control patients $(n=20)$ and patients infused with esmolol $(n=20)$ during the neurosurgical operations under the general balanced anaesthesia

\begin{tabular}{lccc}
\hline Parameter (unit) & $\begin{array}{c}\text { Control } \\
\text { (mean } \pm \text { SE) }\end{array}$ & $\begin{array}{c}\text { Esmolol } \\
\text { (mean } \pm \text { SE) }\end{array}$ & $\begin{array}{c}\text { Statistical } \\
\text { significance }\end{array}$ \\
\hline Age (years) & $49.58 \pm 3.62$ & $46.75 \pm 5.12$ & $\mathrm{~ns}$ \\
\hline Body mass (kg) & $81.17 \pm 3.55$ & $76.83 \pm 3.20$ & $\mathrm{~ns}$ \\
\hline Gender: Male/Female & 12 vs 8 & 12 vs 8 & $\mathrm{~ns}$ \\
\hline Systolic blood pressure & $142.08 \pm 5.42$ & $153.92 \pm 9.12$ & $\mathrm{~ns}$ \\
\hline Diastolic blood pressure & $92.50 \pm 1.90$ & $89.42 \pm 3.00$ & $\mathrm{~ns}$ \\
\hline Heart rate & $85.50 \pm 2.55$ & $92.15 \pm 4.47$ & $\mathrm{~ns}$ \\
\hline SE - standard error of the mean; $n s-$ not significant &
\end{tabular}

$S E$ - standard error of the mean; $n s$ - not significant

Values of cardiovascular parameters - systolic blood pressure, diastolic blood pressure and heart rate - in critical phases of anaesthesia and operation are shown in Figures 1, 2 and 3, respectively.

It is obvious from the Figure 1 that in all the critical phases of anaesthesia and operation, with the exception of the intubation phase, esmolol group of patients had significantly lower values than the patients from the control group.

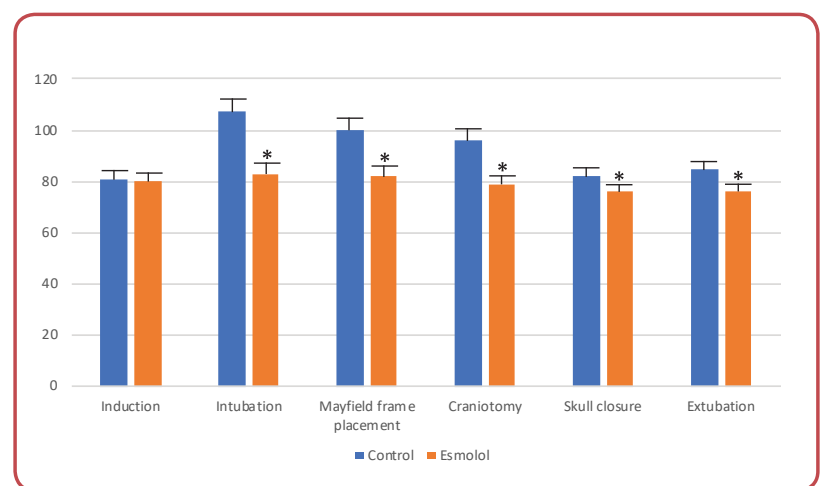

Figure 1: Systolic blood pressure in various phases of anaesthesia and operation in control patients $(n=20)$ and patients infused with esmolol $(n=20)$ during the neurosurgical operations under the general balanced anaesthesia*

*Values are expressed as percentages of pre-induction values (mean \pm standard error of the mean)

There were no significant differences between the values of the diastolic pressure between the control and esmolol group of patients (Figure 2).

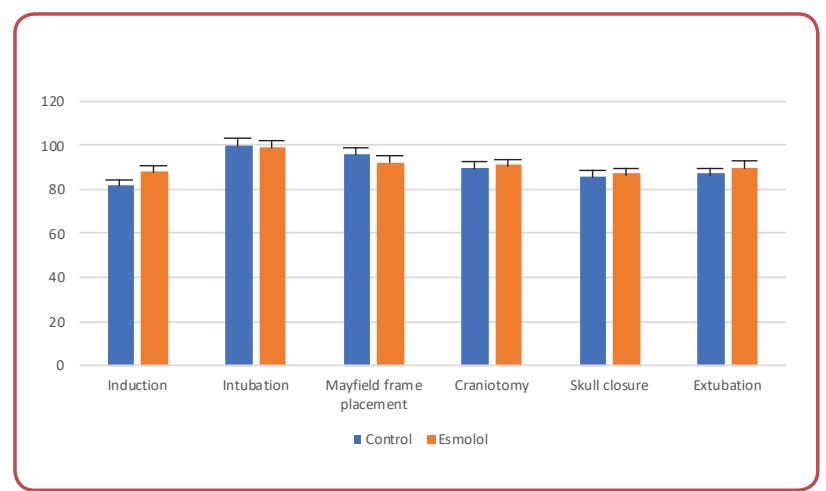

Figure 2: Diastolic blood pressure in various phases of anaesthesia and operation in control patients $(n=20)$ and patients infused with esmolol $(n=20)$ during the neurosurgical operations under the general balanced anaesthesia*

*Values are expressed as percentages of pre-induction values (mean \pm standard error of the mean)

Regarding the heart rate, it was obvious that patients from the esmolol group had not only significantly lower values than the control patients throughout the anaesthesia and operation, but also had very stable heart rate values in all the critical phases (Figure 3).

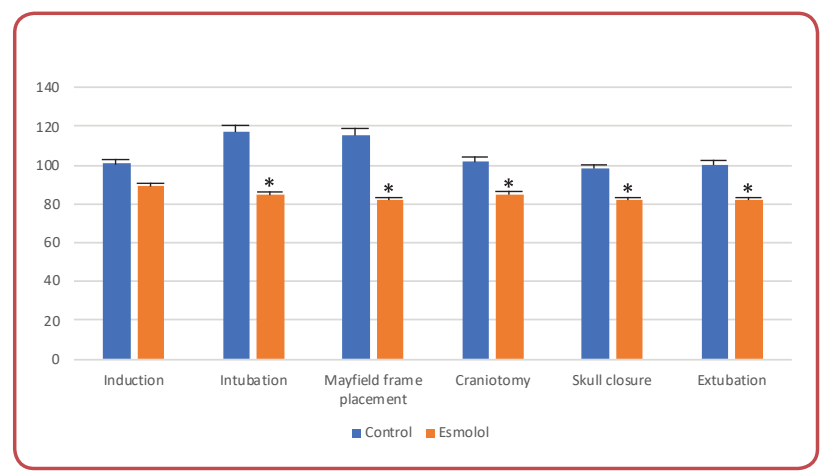

Figure 3: Heart rate in various phases of anaesthesia and operation in control patients $(n=20)$ and patients infused with esmolol $(n=20)$ during the neurosurgical operations under the general balanced anaesthesia*

${ }^{*}$ Values are expressed as percentages of pre-induction values (mean \pm standard error of the mean)

Table 2: Consumption of medicines in control patients $(n=20)$ and patients infused with esmolol $(n=20)$ during the neurosurgical operations under the general balanced anaesthesia

\begin{tabular}{lccc}
\hline Drug (unit) & $\begin{array}{c}\text { Control } \\
\text { (mean } \pm \text { SE) }\end{array}$ & $\begin{array}{c}\text { Esmolol } \\
\text { (mean } \pm \text { SE) }\end{array}$ & $\begin{array}{c}\text { Statistical } \\
\text { significance }\end{array}$ \\
\hline Fentanyl $(\mathrm{mg})$ & $1.30 \pm 0.14$ & $0.49 \pm 0.09$ & $\mathrm{p}<0.01$ \\
\hdashline Droperidol $(\mathrm{mg})$ & $23.13 \pm 2.99$ & $7.08 \pm 1.34$ & $\mathrm{p}<0.01$ \\
\hdashline Atropine $(\mathrm{mg})$ & $1.08 \pm 0.08$ & $0.92 \pm 0.08$ & $\mathrm{~ns}$ \\
\hdashline Pancuronium $(\mathrm{mg})$ & $16.50 \pm 1.67$ & $11.00 \pm 1.18$ & $\mathrm{p}<0.05$ \\
\hdashline Isoflurane & 50.00 & 10.00 & $\mathrm{p}<0.05$ \\
(\% of patients) & & & \\
\hline SE - standard error of the mean; $n s$ - not significant &
\end{tabular}

All the medicaments, including fentanyl and isoflurane, were used in significantly larger quantities in patients from the control group, in com- 
parison with the patients treated with esmolol (Table 2). The only exception was use of atropine that did not differ between the groups.

Table 3: Effect of esmolol on speed and quality of postoperative recovery in control patients $(n=20)$ and patients infused with esmolol $(n=20)$ during the neurosurgical operations under the general balanced anaesthesia

\begin{tabular}{|c|c|c|c|}
\hline Parameter (unit) & $\begin{array}{c}\text { Control } \\
\text { (mean } \pm \text { SE) }\end{array}$ & $\begin{array}{c}\text { Esmolol } \\
(\text { mean } \pm \text { SE) }\end{array}$ & $\begin{array}{l}\text { Statistical } \\
\text { significance }\end{array}$ \\
\hline $\begin{array}{l}\text { Duration of } \\
\text { anaesthesia (min) }\end{array}$ & $174.17 \pm 16.62$ & $170.00+18.64$ & ns \\
\hline $\begin{array}{l}\text { Opening of eyes on } \\
\text { command (min) }\end{array}$ & $16.33 \pm 1.94$ & $4.40 \pm 1.21$ & $p<0.01$ \\
\hline $\begin{array}{l}\text { Spontaneous opening } \\
\text { of eyes (min) }\end{array}$ & $25.20 \pm 3.09$ & $10.70 \pm 2.70$ & $\mathrm{p}<0.01$ \\
\hline Full orientation (min) & $29.83 \pm 3.34$ & $16.00 \pm 3.85$ & $p<0.05$ \\
\hline $\begin{array}{l}\text { Extubation possible } \\
\text { (\% of patients) }\end{array}$ & 50.00 & 90.00 & $p<0.05$ \\
\hline $\begin{array}{l}\text { Evaluation of quality } \\
\text { of anaesthesia }\end{array}$ & $1.50 \pm 0.15$ & $2.17 \pm 0.17$ & $\mathrm{p}<0.01$ \\
\hline
\end{tabular}

SE - standard error of the mean; $n s$ - not significant

Patients in the esmolol group had a tendency to recover from anaesthesia quicker than the patients from the control group (Table 3).

At the same time, the mean duration of operation in both groups was similar and yet extubation in the operation theatre was possible in almost all patients in the esmolol group, while this was the case in only half of the control patients.

\section{Discussion}

The results of this study show that the continuous esmolol infusion assured cardiovascular stability enabling a decreased use of additional opioids and anaesthetics, which in turn resulted in better post-anaesthesia recovery.

These results are in general agreement with the results of other clinical trials. Indeed, injection and/or iv infusion of esmolol alleviated increases in blood pressure and heart rate induced by tracheal intubation ${ }^{9}$ and extubation in neurosurgical patients. ${ }^{10-17}$ Especially this effect at the end of the neurosurgical operation, after the extubation of trachea and in the immediate post-anaesthesia recovery period seems to be vitally important in neurosurgery, since esmolol blocks the beta ${ }_{1}$-adrenergic receptors and prevents the sympathetic overdrive-induced cerebral hyperaemia. ${ }^{11,18-20}$
Since opioid analgesics control painful stimuli and thus blunt the sympathetic nervous system reflexes, use of a beta-blocker like esmolol assures the similar outcome, however without additional doses of opioids or inhalation anaesthetics. The present study showed a significant opioid-sparing effect of esmolol and so did some other clinical trials. ${ }^{21-23}$ Various publications even report on the decreased need for the administration of intravenous and inhalation anaesthetics as a result of esmolol iv bolus or infusion..$^{24,25}$ In the present study similar result was obtained, since there was a significantly lower need for isoflurane addition in the esmolol group, as compared to the control group of patients.

Although similar effects of esmolol were obtained as regards to the systolic blood pressure and heart rate, its effect on the values of heart rate were more accentuated than the ones on the blood pressure, which is in accordance with the findings of Ornstein et al, who found that the half-time for the $14 \%$-decrease in heart rate was only $1.2 \mathrm{~min}$, as compared to the half time of $17.8 \mathrm{~min}$ for the $25 \%$-decrease in mean arterial blood pressure. ${ }^{26}$

Besides esmolol, some other agents were tried with the same aim to control reflex sympathomimetic reactions resulting from laryngoscopy and intubation ${ }^{27}$ or from tracheal extubation. ${ }^{28}$ It seems that esmolol should be preferred over nitroglycerin ${ }^{29}$ or lidocaine, ${ }^{30}$ while dexmedotimidine ${ }^{27}$ or nicardipine ${ }^{28}$ could be more efficient than esmolol.

\section{Conclusion}

Ultrashort-acting beta-adrenergic receptor antagonist esmolol, administered as a continuous iv infusion, assures better cardiovascular stability and smoother emergence from the balanced inhalation general anaesthesia than the control glucose infusion in elective neurosurgical patients.

\section{Acknowledgements}

None. 


\section{Conflict of interest}

None.

\section{References}

1. Wolf AR. Effects of regional analgesia on stress responses to pediatric surgery. Paediatr Anaesth 2012 Jan;22(1):19-24.

2. Egan TD. Are opioids indispensable for general anaesthesia? Br J Anaesth 2019 Jun; 122(6):e127-e135. doi: 10.1016/j.bja.2019.02.018.

3. Gorczynski RJ, Murthy VS, Hwang TF. Beta-blocking and hemodynamic effects of ASL-8052. J Cardiovasc Pharmacol 1984 Nov-Dec;6(6):1048-59.

4. Girard D, Shulman BJ, Thys DM, Mindich BP, Mikula SK, Kaplan JA. The safety and efficacy of esmolol during myocardial revascularization. Anesthesiology 1986 Aug;65(2):157-64.

5. Harrison L, Ralley FE, Wynands E, Robbins GR, Sami $\mathrm{M}$, Ripley R, et al. The role of an ultra short-acting adrenergic blocker (esmolol) in patients undergoing coronary artery bypass surgery. Anesthesiology 1987 Mar;66(3):413-8.

6. Lončar-Stojiljković D. Effects of esmolol infusion on cardiovascular parameters and quality of general anaesthesia in younger and older patients. Scr Med 2021 Jun;52(2):109-14.

7. Lončar-Stojiljković D. Effects of the ultra-short-acting beta-blocker esmolol infusion on cardiovascular parameters and quality of postoperative recovery in patients scheduled for elective plastic surgery. Scr Med 2021 Sep;52(3):187-92.

8. Sharma A, Ramaswamy S, Bhatia SC. Electroconvulsive therapy after repair of cerebral aneurysm. J ECT 2005 Sep;21(3):180-1.

9. Samaha T, Ravussin P, Claquin C, Ecoffey C. [Prevention of increase of blood pressure and intracranial pressure during endotracheal intubation in neurosurgery: esmolol versus lidocaine]. Ann Fr Anesth Reanim 1996;15(1):36-40.

10. Alkaya MA, Saracoglu KT, Pehlivan G, Eti Z, Gogus FY. Effects of esmolol on the prevention of haemodynamic responses to tracheal extubation after craniotomy operations. Turk J Anaesthesiol Reanimatol 2014 Apr;42(2):86-90.

11. Bhagat H, Dash HH, Bithal PK, Chouhan RS, Pandia MP. Planning for early emergence in neurosurgical patients: a randomized prospective trial of low-dose anesthetics. Anesth Analg 2008 0ct;107(4):1348-55.

12. Wiest D. Esmolol. A review of its therapeutic efficacy and pharmacokinetic characteristics. Clin Pharmacokinet 1995 Mar;28(3):190-202.

13. Cuneo BF, Zales VR, Blahunka PC, Benson DW Jr. Pharmacodynamics and pharmacokinetics of esmolol, a short-acting beta-blocking agent, in children. Pediatr Cardiol 1994 Nov-Dec;15(6):296-301.

14. Gibson BE, Black S, Maass L, Cucchiara RF. Esmolol for the control of hypertension after neurologic surgery. Clin Pharmacol Ther 1988;44(6):650-3.

15. Grillo P, Bruder N, Auquier P, Pellissier D, Gouin F. Esmolol blunts the cerebral blood flow velocity increase during emergence from anesthesia in neurosurgical patients. Anesth Analg 2003 Apr;96(4):1145-9.
16. Bilotta F, Lam AM, Doronzio A, Cuzzone V, Delfini R, Rosa G. Esmolol blunts postoperatie hemodynamic changes after propofol-remifentanil total intravenous fast-track neuroanestehsia for intracranial urgery. J Clin Anesth 2008 Sep;20(6):426-30.

17. Hosseinzadeh H, Eydi M, Ghaffarlou M, Ghabili K, Golzari SEJ. Esmolol: a unique beta-blocker in maintaining cardiovascular stability following neurosurgical procedures. Adv Pharm Bull 2012;2(2):249-52.

18. Bruder N, Ravussin P. Recovery from anesthesia and postoperative extubation of neurosurgical patients: a review. J Neurosurg Anesthesiol 1999 Oct;11(4):28293.

19. Basali A, Mascha EJ, Kalfas I, Schubert A. Relation between perioperative hypertension and intracranial hemorrhage after craniotomy. Anesthesiology 2000 Jul;93(1):48-54.

20. Bruder NJ. Awakening management after neurosurgery for intracranial tumours. Curr Opin Anesthesiol 2002;15:477-82.

21. Lee MH, Chung MH, Han CS, Lee JH, Choi YR, Choi EM, et al. Comparison of effects of intraoperative esmolol and ketamine infusion on acute postoperative pain after remifentanil-based anesthesia in patients undergoing laparoscopic cholecystectomy. Korean J Anesthesiol 2014 March;66(3):222-9.

22. de Morais VBD, Sakata RK, Huang APS, da Cunha Ferraro LH. Randomized, double-blind, placebo-controlled study of the analgesic effect of intraoperative esmolol for laparoscopic gastroplasty. Acta Cir Bras 2020;35(4): e202000408. doi: 10.1590/s0102865020200040000008.

23. Mendonca FT, Tramontini AJ, Miake HI, Seixas LF, de Carvalho LSF, Sposito AC. Intra-operative esmolol and pain following mastectomy: A randomised clinical trial. Eur J Anaesthesiol 2021 Jul 1;38(7):735-43.

24. Asouhidou I, Trikoupi A. Esmolol reduces anesthetic requirements thereby facilitating early extubation; a prospective controlled study in patients undergoing intracranial surgery. BMC Anesthesiology 2015 Nov 28;15:172. doi: 10.1186/s12871-015-0154-1.

25. Gruenbaum SE, Meng L, Bilotta F. Recent trends in the anesthetic management of craniotomy for supratentorial tumor resection. Curr Opin Anaesthesiol 2016 Oct;29(5):552-7.

26. Ornstein E, Young WL, Ostapkovich N, Matteo RS, Diaz J. Are all effects of esmolol equally rapid in onset? Anesth Analg 1995 Aug;81(2):297-300.

27. Srivastava VK, Agrawal S, Gautam SKS, Ahmed M, Sharma S, Kumar R. Comparative evaluation of esmolol and dexmedetomidine for attenuation of sympathomimetic response to laryngoscopy and intubation in neurosurgical patients. J Anaesthesiol Clin Pharmacol 2015 Apr-Jun;31(2):186-90.

28. Bebawy JF, Houston CC, Kosky JL, Badri AM, Hemmer LB, Moreland NC, et al. Nicardipine is superior to esmolol for the management of postcraniotomy emergence hypertension: a randomized open-label study. Anesth Analg 2015 Jan;120(1):186-92.

29. Guney A, Kaya FN, Yavascaoglu B, Gurbet A, Selmi NH, Kaya S, et al. Comparison of esmolol to nitroglycerine in controlling hypotension during nasal surgery. Eurasian J Med 2012 Aug;44(2):99-105.

30. Dogan SD, Ustun FE, Sener EB, Koksal E, Ustun YB, Kaya C, et al. Effects of lidocaine and esmolol infusions on hemodynamic changes, analgesic requirement, and recovery in laparoscopic cholecystectomy operations. Braz J Anesthesiol 2016;66(2):145-50. 